\title{
Oak Ridge Building Trades Medical Screening Program for Portsmouth \& Paducah Gaseous Diffusion Plants
}

\author{
University of Cincinnati \\ Eula Bingham, $\mathrm{Ph} . \mathrm{D}$. \\ Knut Ringen, Dr. P.H. \\ William J. McGowan, B.S. \\ Co-operative Agreement with the U.S. Department of Energy \\ DE-FC02-96SF-21263 \\ Final Report \\ August 2007 \\ 1. Institutional History Databases and Interyiews to Ascertain Risks and Health \\ Institutional History Databases for the Portsmouth GDP and Paducah GDP were \\ completed using historical documents, the PACE Needs Assessment, and worker \\ comments. Examples from the Institutional History Database for each site are \\ included in Appendix A. The Oak Ridge interview was modified for use at the \\ Portsmouth and Paducah GDP's.
}

\section{Concerns}

\section{Outreach to Portsmouth GDP Workers}

a) February 2003, Eula Bingham and Bill McGowan (University of Cincinnati), and Mike Dorsey (CPWR) met with the Tri-States Building and Construction Trades Council (Portsmouth GDP) to describe the screening program and encourage participation.

b) October 2003, at the request of the Tri-States Building and Construction Trades Council, Eula Bingham and Bill MoGowan, Mike Dorsey and Trish Quinn (CPWR), Kim Cranford and Sue Boone (Zenith Administrators) presented additional program information to a meeting in Portsmouth, Ohio attended by approximately 250 construction workers and community members and answered their questions.

c) The Tri-States Building and Construction Trades Council polled their members and identified 825 GDP construction workers who have expressed an interest in screening. As a result of local media coverage, additional interested workers have called. Altogether, more than 1,145 former Portsmouth GDP construction workers expressed interest in participating in the program and 650 have been interviewed as of November 30,2006. Medical exam diagnoses from exams completed by this date are provided in Appendix B. Results of medical exams authorized before December 1, 2006 for Portsmouth GDP construction workers, which have been completed and entered into the DMS, are included in quarterly reports submitted by CPWR 
for the Building Trades National Medical Screening Program.

3. Opened Portsmouth GDP Office in December 2003 and Started Screnings

a) Identified, hired, and trained a building trades worker to be the interviewer.

b) Rented space at a centrally-located office for inferviews and outreach.

c) Screening exams began on January $22,2004$.

\section{Outreach to Paducath GDP Workers}

a) May 2003, Eula Bingham and Mike Dorsey (CPWR) met with the West Kentucky Building and Construction Trades Council (Paducah GDP) to describe the screening program and encourage participation.

b) The West Kentucky Building and Construction Trades Council polled their members and identified 650 GDP construction workers who have expressed an interest in screning. Local media coverage of the interview and outreach office opening resulted in numerous telephone calls from interested workers. Altogether, more than 1,035 former Paducah GDP construction workers expressed interest in participating in the program and 627 have been interviewed as of November 30,2006. Medical exam diagnoses from exams completed by this date are provided in Appendix C. Results of medical exams authorized before December 1, 2006 for Paducah GDP construction workers, which have been completed and entered into the DMS, are included in quarterly reports submitted by CPWR for the Building Trades National Medical Screening Program.

\section{Opened Paducah GDP Office April 2004 and Started Screenings}

a) Identified and hired, and a building trades worker to be the interviewer.

b) Rented space at a centrally-located office for interviews and outreach.

c) Training of the interviewer and first interviews in May 2004; medical exams began May 10, 2004.

6. Additional Outreach Activities

a) The DOE-Lexington Office staff, now responsible for operations at the Portsmouth and Paducah GDP's, and Bechtei-Jacobs representatives at both sites were kept informed and prepared for questions that may come to them as a result of our outreach and medical exam activities.

b) DOE Lexington Office staff were contacted for assistance in locating records that would identify former construction workers at the Portsmouth and Paducah GDP sites to facilitate contacting and notifying them about the 
program. Laura Schachter of the DOE Lexington Office identified Steven A. Wagner of the United States Enrichment Corpotation (USEC) as the contact person to assist us. A meeting with Steve Wagner (USEC Paducah) and Shannon E. Coriell (USEC Portsmouth) was held on June 17, 2004 at the Portsmouth GDP.

c) The information provided by USEC was limited to construction worker and contractor names from visitor logs at Portsmouth GDP for various periods between 1983 and 1992 and at Paducah GDP for various periods between 1976 and 1991. The information we requested to facilitate former wotker rectuitment including name, $\mathrm{SSN}$, and last known address and/or telephone number was said to have been available, but was never approved for release by the DOE Lexington Office.

d) November 2006, Eula Bingham and Bill McGowan (University of Cincinnati), George Jones and Trish Quinn (CPWR), and Kim Cranford (Zenith) met with the Tri-States Building and Construction Trades Council (Portsmouth GDP) to inform them of the program's transition to the Building Trades National Medical Screening Program scheduled to occur on December 1, 2006. In February 2007, Eula Bingham and George Jones met with the West Kentucky Building and Construction Trades Council (Paducah GDP) to inform them of the program's transition to the Building Trades National Medical Screening Program which oecurred on December 1, 2006.

\section{Protocol Manual and IRB}

A revised protocol manual for the Oak Ridge Building Trades Medical Screening Program for the Portsmouth and Paducah GDP's was prepared and submitted to the Program Office, the Oak Ridge Site-Wide IRB (ORSIRB) and the Central Beryllium IRB (CBeIRB). The program at both sites was approved by both IRB's.

The Oak Ridge Site-Wide IRB (ORSIRB) and the Central Beryllium IRB (CBeIRB) were both notified in writing that the administrative responsibility for the Oak Ridge Building Trades Medical Screening Program for the Portsmouth and Paducah GDP's would transition from the University of Cincinnati to The Center to Protect Workers' Rights on December 1,2006 and be incorporated into the Building Trades National Medical Soreening Program. 


\section{Report of Bailding No $X-345$}

Date Constructed; 1978 Yoar Closed: 2009

Construction Type:

$$
\text { Stze: } 36,061 \text {. ft. (914.04, p. C-5) }
$$

Unique Fentares:

Renowations:

\section{Function-Table}

Year Function

1978 Special Nuckear Materials Siorege Building (909.01, p. 7)

\section{ProcessuTable}

\begin{tabular}{|c|c|c|c|}
\hline From year & To year & Procest & \\
\hline & & $\begin{array}{l}\text { X-345 glovebox wess orlginally used for sampling of uranlum } \\
\text { oxdde by the uranium recovery operations, and hed a particulate } \\
\text { sampler on the exhaust. For several years, it was used only for } \\
\text { repackag!ng of demaged oxide containers ( }(914 ; 03, p, 65)\end{array}$ & \\
\hline & & $\begin{array}{l}\text { The central area houses a hlgh-assay sampling area (HASA) } \\
\text { and a small taboratory }(909.01, p .7)\end{array}$ & \\
\hline & & $\begin{array}{l}\text { North and South Vaults stored highly enrlched urenturn (HEL) } \\
\text { (909.01. p. } 7)\end{array}$ & \\
\hline 1978 . & & $\begin{array}{l}\text { X-345 was designed to fill the mission of X-744G for atorage of } \\
\text { HEU materials in a more securs envrorment. After initlal } \\
\text { construction, it was also used to sample HEU UFB small } \\
\text { diameter' cylinders using aulochaves ( } 914.02, \text { p. 46) }\end{array}$ & \\
\hline 1986 & & Fourteen ton cyllnders stored $(904.02, p .11)$ & \\
\hline
\end{tabular}

\section{Contaminations}

Year Contamination

Some metal HEU oxdde storage cantalners have been opened and not resealed with a new lid $(810.01$. p. 32). 
DOE described the sampling faclity as a source of fluorlde and uraniturn erriseions (909.01, p. 7)

The entire bułding has been designated as hoving fixed radiological contamination (909,01, p. 7)

The area around the HASA was known to be contaminated. (909.01, p. 7)

1978 Due to its high atomlc weight, and because thoritum-230 is a decay product of $U$ 234, It tends to concenlrate wilt the highly anliched U.235 stored in Building X345. This makes the alphe emfting Th230 an Inhalation hazard for workers in the area. (915.10, p. 10)

T978 Mast uptakes of uranium indicate a fast indticate a fast absoiption type unless otherwise indlagted in the bloassay records. Both Th-230 and U-234 should be considered as prediominant radionuclides. Ambient gamme and neutron radiation are of conorarn. (915.10, p. 11)

Eszards: racietlom, urenium, fluoride (909,01, p. 7), highly enriched aranimem (KDEC) (909,01, p. 7), bighly entiched urgnsum oxide (810.10, p. 32), UF6 (914.02, p. 45), U274, Th230, atpha radlation, ambient germma and neutron radiation (915.10, p. I0, 11 )

interrexi hazards:

\section{References}

810.01 Highty Enriched Uranium Working Group Report on Environsontal Safety and Health Vulnerablities Associated with Department's Storage of Highly Enrichod Uranimen, Vol. I, DOR/EH-0525; U.S. Depentment of Enorgy, Decernber 1996.

904,02

Ipdependent investigation of the Portamouth Gaseous Diffusion Plant, Vol. II: Cumrent Environment, Safety, and Health Practices, Propared by Oftice of Oversight of Environment, Safety, and Health, U. S. Department of Enorgy, May, 2000.

909.01 A Guide to Key Facilities at the Portsmoulh Gaseons Dlffusion Plant, Mary Byrd Davis; Urauium Enrychunent Project, Yggatrasil Institute, madnted.

914.02 Recycled Ukanium Mass Balence Project Portsmouth, Ohio Ste Report, BJG/PORTS-

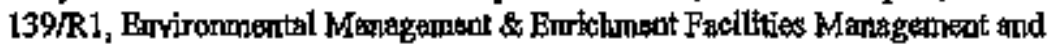
Integration Contraot, June 19,2000.

914.03 Public Health Assossment- US DOE Portsmouth Gasepus Diffussion Plart Piketor,

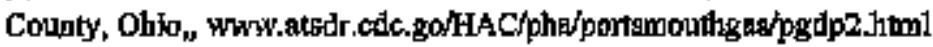

914,04 Environmental Assessment Roindustralialization Program at the Ptrtsmouth Gasecus Diffusion Plant Plketon, Ohio, Drath, U.S. Departmest of Energy, Cak Ridgo Operations Office, Oak Ridgs, Tennesspe, May 2001.

915.10 OKAU Team Nrosh Dose Roconstwetion Project; Tochnical Besis Doement for Portsmounth Gaseous Diffision Plam-Sit Description; ORAU-TKBS-0015-2: November 18,2003 , 
Report of Building No $X-616$

Date Constructed: $1976 \quad$ Year Closed: 1992

Construction Type:

Size:

Uniqué Fragtures;

Renorationst Enrily 1980s-CPVC pipeline constrwated to roroute efflvents to X-616 via the RCW blowdown lines $(909.02$, p. A- 62$)$

Function-Table

\begin{tabular}{ll}
\hline Year & Function \\
\hline 1976 & Llquld Effiluent Control Facll'ty $(909.02$, p. A-62) \\
$\uparrow 976$ & Chromate Reductlon Facillity (904.01, p. 68)
\end{tabular}

Process-Table

\begin{tabular}{|c|c|c|}
\hline From year & Toyear & Process \\
\hline 1976 & 1990 & Treated water was piped to the Scloto River (909,01, p. 18). \\
\hline 1976 & 1990 & $\begin{array}{l}\text { The chromlum hydroxlde sludge formed as a result of treating } \\
\text { hexavalent chromium and was stored in two surface } \\
\text { Impoundiments to the west of the factllty. Closure began in } \\
1990 \text {. At that thme shdge was removed, treated, and bakers to } X \text { - } \\
736 \text { (009.01, pp. } 17-18)\end{array}$ \\
\hline 1976 & 1990 & Also, treated effiluent from $X-700$ and A-705 $(900.01, p, 1 B)$ \\
\hline 1978 & 1990 & 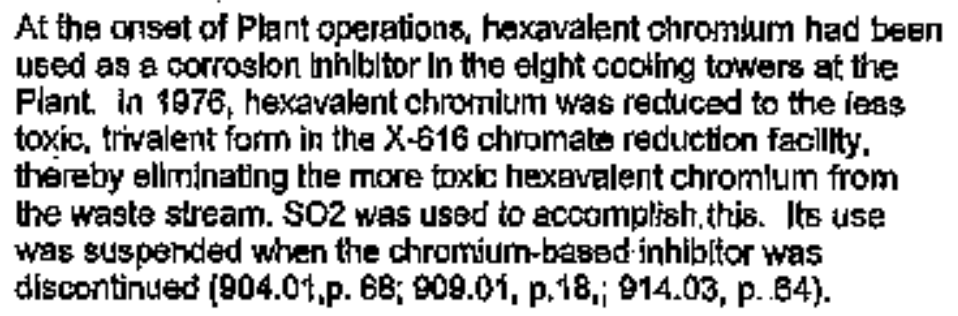 \\
\hline 2000 & & $\begin{array}{l}\text { More than six millon pounds shlpped to Emvirocere in Utah } \\
\text { (909.01, p.18) }\end{array}$ \\
\hline
\end{tabular}




\section{Contaminations}

Yaar Contamination

Inorgantc constituents Including chromlum, nickel, manganese, and TCE have been defected in groundwater asschteted with the $X-816$ area $(914.04,0.3-10)$.

1997 The maximum concentrations of hexavalent chromium and total chromkum were 20 micrograms/itter and 1560 microgramsilter respectively $(909.02$, p.18)

Hazards: hexavalent chromíln, trivalent, $802(904,01, p, 68)$, nickel, manganeso, TCE (914.04, p. 3-10), \$02 (914.03, p. 64)

Inferred hezarda:

\section{References}

904.01 Indeppendent Invertigation of the Portmouth Gassous Diffusion Piant, Vol. I: Past Euvironment, Safety, and Hoalth Practices, Prepared by Office of Oversigat of Euviromment, Safety, and Health, U.S. Department of Energy, May 2000.

909,01 A Gujdo to Key Facilities at the Portsmouth Gaseous Diffizsion Plant, Mary Bynd Davis; Urarimm Finriefiment Project, Yegdrasil Institute, undated

969.02 Infomation Briefing on the Natural Reacurce Damago Assessment Rule, Presented to the Portsmouth Gaseous Diffusion Plent Tnustees, U.S. Dopartment of Energy Field Oftice, Oak Ridge, December 18, 199].

914.03 Pubtic Heslth Assessment-US DOB Portsmouth Gaseous Diffussion Plant Piketom, County, Ohion www.atsdr.odc.go/HAC/pha/porttemouthgas/pgdp2.html

914.04 Envlonment Assessment Retindustrializatlom Program at the Pontsmouth Gageous Diffision Plant Piketon, Ohì, Draft, U.S. Depentment of Energy, Olk Ridge Operatipns Office, Oak Ridge, Tejpessag, May' 2001. 


\section{Report of Butlding No $X-760$}

Date Constructed: 1953 Year Closed:

Construction Type:

$$
\text { Sizx: }-60 \text { by } 80 \text { ft }(909.02, \text { p. A-47) }
$$

Unique Featmres: 2000 gal, neutralization pit (909.02, A-47)

Rentovations;

\section{Function-Table}

\begin{tabular}{|c|c|}
\hline Yoar & Function \\
\hline 1953 & Pllot Invesligatlon Building $(900,02$, p. A-47) \\
\hline 1954 & $\begin{array}{l}\text { Chemlcal Engineerfing Butilding (Entironmental Assessment Reindustriallzation } \\
\text { Program Dodument uses this name) (914.04, p. C-9) }\end{array}$ \\
\hline
\end{tabular}

\section{Process-Table}

From year To year Process

$X-760$ contialned a small process laboratory, a small machinelfabrication shop, a worker change/shower area, and essentlally all plantsfte utifities $(914.02$, p. 44)

This bullding was used for chemical and mechanical engineering pilót and demonstration scole investigations, "Early development projects, inciuding decontaininatlon process experiments, boillng freon heat exchanger experiments, UFb heating studies, uranium oxdde pellettzing expertinents, freon drylng tests, and controlled UFB releases in a sealed enwironmental chamber, were condiucted In this facilfy." Development work on the "fluórox process," which appeared to have involved a protodype ffuorination tower for the Feed Manufacturing or Oxade Conversion Facility (909.01, p. 15; 909.02, p. A-47)

The teutralization pit, noth of X-760, was assoclated with X-760 for the storage and transfor of chemical wastes. The wasto charateter varied according to the operations in X-760. The waste soilds have contained urarlum, nlckel, and PCEs. $\left(909,02, p_{+}, A-48\right)$ 
1955

Some of the wastes generated in the X-710 Labofatory were discharged to the sanitary sewers wa the neutralization pit located in $X-760$. These included polassium fluoride, potassium hyoroxide, and waste oil (909.02, p. A-48).

1957

$X-760$ received $0.8 B$ MTU of UFA, 0.4 MTU of UOZ, and $3.3 T U$ of UO3 from K-25. It was classffied as recycled uranfum. (909.01, p. 15)

Hazırds: uranium, nickel, PCBs, potasstum fluorlde, potassium hydroxide, waste ofl (909.02, p. A-48), (1TFA, UO2, UOO3 $(909,01)$

Inferred haxerds:

\section{References}

909.01 A Guide to Key Racilicies at the Portsmouth Gaseous Dlffusion Plant, Mary Byrd Davis; Uranium Eurlchment Project, Yggdrasll Insthute, uthdated.

909.02 Infonmation Briofing on the Nahural Resource Damego Assesement Rule, Presentod to the Portsmouth Gaseous Diffiston Plemt Trustess, U.S. Department of Exergy Fie]d Office, Oak Ridge, Decenter 18, 1991.

914.02 Recycled Uranium Masi Balance Project Portsmouth, Ohto Site Report, BfCfPORTS139/Ri, Bnvhommontal Managemosat \& Entichnent Facilities Mansgement and Integration Contrast, Jime 19, 2000.

914.04 Envirommental Aasessment Reindustralialization Progran at the Portsmouth Gaseous Diffusion Plant Piketru, Ohio, Draft, U.S. Departinont of Energy, Oak Ridgo Operations Office, Oak Kidge, Tennessec, May 2001. 


\section{Report of Building No C-746A}

Date Constructed:

Yoar Closed:

Construction Type:

Skze;

Uniquge Features:

Renovations:

\section{Function-Table}

\section{Year Function}

1952 Smelter $[404,0$ t, p. $60,414,20$, p. 1)

\section{Process-Table}

From year To year Procesa

Pantex shipped foam and plastics contarninated with beryllium, tritium, and uranium ox[de. The foam and plastics were temporaily piled th a comer untll an amotint large enough to fill the burial container was collected. (414.04, p. 17) Also, ciled in "Needs Assessment for Screenthg Formor Paducah and Portamouth GDP Workers for Beryllurn Exposure" (967.02, p. 5)

1985 Three smelters operated in C-748A, inçluding a nlekel lnduction furence, a reverteratory furnance used to melt clean aluminium, and an aluminium aweating fumance. Little daja on smetter operattons at the plant was available beceuse records were stored in contaminated waste drums or ware removed by a DOE team Invesilgating scrap metal recovery at the Plant. (404.01, p. 60)

Lead fabricartlon work such as the pouring of melted lead to form massive shielding doors. It is estimated that approximately 10-20 tons of lgad were used in the door. Additionad doors were made in 1971 and 1978-1979. (414.04, ppp 9-10) 
Large quantitles of clasin and contaminated nlckel powder were recovered by smelting into ingots in Builnding C-74tie. One or more sample buttons were made with each pour. Approxilnately 17 million pounds of clean hickel were released into commerce. Nickel free of radloactivity and that which was below the AEC and stie criteria were routinely transferred to the Nalional Stockplle or sold. Nearly 20 million pounds of this melerial was sold or otherwhe released from radologlcal control, and the materied to currently malntained in the PGDP contaminaled scrap yard. Samples of "clean" ingots solt into commerce contalned low levels of both Te 99 and plutonlum 239 contamlnation. $(414.03, \mathrm{p} .2)$

Lead was received and recowered from geveral sousces, hinclucing weepons parts. The Smeltar Production Logbooks indicate approximately $258,990 \mathrm{lbs}$ of shredded lead were produced and sold into commerce. $(414.03, p .22)$

About 37 million pounds it n]ckel were smelted [414.20, $p$.

in the 1950's, earhy smelting activities mainly inwohved aluminilum. $(4 \div 4,02$, p. 13

The nicket was first ground to produce a small, uniform feed material. The process occurred in enclosed containers and emiesions were subject to filtration before release to the atmosphere. All nickel was run through a large calciner to remove hydrogen fluoride from the scrap before it was fed to the smelter. Particulates and gas from thls process were rekeased to a chemical trap system that did not function well. $(414.20$, p. 7$)$

Nickel realeases from all sources ware predominately in a niokel oxhde form. Parlloulate releases from the simelter were predominately about 30 microns in diameter with a small fraction in the 10 and 20 micron dlameter sizerangag.

Gold-bearing scrap was accumulated in C-746A before it was transported in lols to C-400 gold recovery area. $(414,03, p .7)$

Approximately 4.5 milion ibs of aluminium were smeited into ingots in Buildring C-746A from 1970-1986. Records prior to 1984 cotdd not be found. Analysis of thuminium samples has revealed low levers of thortum-230, Pu 239,.Pu-240, and wanium 233. Both aluryinium melting fumances were used to melt classiffed aluminium serap (ckean and contaminated) received from various locations. Meliting was necessary to destroy the classiffed nature of the material. The Sweat Fumance was used solely to melf clean aluminlum scrap and the Reverberatory Fumance was used to melt conteminated alumin [um acrap. Approximately 4.5 mifilon lbs. of aluminilum was processed into ingots and sold into commerce. (414.03, p. 2, 17) smelted. $(414.20$, p. 1$)$ 
The major process soluce of the monel (a copper-nickel alloy) was the manufacture of new bairler. Monel Was used to fabricale the ferrules of the barrier tube. Off-specification monel feedbeck and monel recovered from off-specification barrier tubes accumulated, and was smelted to be destroyed for ctassification concerns, and sold for recyole. Cobelt was used as a consunbable component of processes at the K-25 Plent. 882,440 Jbs of monel were released Into conmerce as wel as 20,800 los of cobalt. 50,700 lbs. of cobalt were "s)ipped to Oak Ridge" ,(414_03, p. 21)

$1983 \quad 1988$ Twesty milion pounds of radjologicaliy contaminated nickel were smelted. $(414.20, p .1)$

Annual smelter nickel emissions were estimated to be 794 pounds per year.

in September 1996, the C-746A facllty was placed in "Standby" As of 2000, the smelter faclity still existed, afthough in a state of disrepair. Coniaminated metal igots are stored near the facility, Including most of the aickel ingots that were made from the recycle of cascade traterials during gasacus diffusion plant improvement programs, Empty casings for nuckar weapon components could be seen above groulyd behind the smelter fachily $(414,04$, pp. 6-9).

On April 29, 1986, a sintering program for a monel-nickel run was sterted, Records indicated that eight 55-gallon drums of monel were mixed with one drum of contaminated inckel pellets, (414.03, p. 21)

\section{Contaminations/lncidents}

Year Contamination

Primary hazards in sinelting opeations were heat, working with molken metaks, noxious fumes, and the potential for airborne radloactive contaminants. (404.01, p. 18)

The highest average ennual nickel concentration at $1000 \mathrm{~m}$ from the smelter was 0.004 ug/can m. $(414.20,0.3$

1962 Probably, nickel partlculates reaching the final stack of the C-746A induction furnence would have been dominaily rickel oxide, releases from the ather portlons of the smelter were composed of oiher nickel compounds. $\{414.20, p .7$

1952. Activiftes of radlologisal contaminants from nickel samples (Th-230, Th-232, U235 and TC-99 and stack emission monitoring (U-234, U-235 and U-238) were used to determine the qugntity of radionucldes released during nickel smelting. (414.20, D. 3)

1972 A 1972 study of redionuclldes in scrap Indlcated the potential for airtorne concentratlons of uran|urf during laading of melting pots; however, no uranium fumes were detacted during alloy melthig or potring. $(404,01, p .60)$

Hazards: beryllium, tritium, uranium oxide $(4 \mid 4,04$, p. 17$)$, uranium, ajumintam, $H F$ (404.01, p. 60, 80), nickel, monel, coppor (414.03, p. 21), mickel oxide (414.20, p. 7), Th-230, Th-232, U-234, U-235, U-238, Tc-99 (414.20, p. 3) 
Enferred hezards;

\section{References}

404.01 Independent Investigation of the Paducab Guseous Diffusion Plant, Phass II, Prepared by Office of Oversight, Office of Environment, Safety, and Health, U.S. Department of Butrgy, Fesbruary 2000 .

414.03 Roport on the Paducals Gasedus Diffission Planit, Metals Recovery Program; Department of Energy, Oak Ridge Operations, December 2000.

414.04 Report on the Patucah Gaseons Diffiusiom Plant "Wokk for Otherg" Prostam Including Weapons Support and Dispostition, Department of Enorgy Oak Ridgo Operations, December 2000 .

414,20

Publlc Health Asessment Paduckh Gaseous Diffision Plant (U.S. DOE) Paduckh, Merncken County, Kentucky, Appendix I: Exposure Assessment of Aibons Nickel and Other Metal Perticulates from Historics Smoher Operations at the Paducah Gaseous

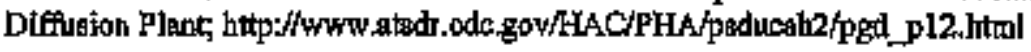
Addendum to PACE Needs Assesament, Paducah and Portsmouth, Mark Griffon, 2900. 


\section{Report of Building No C-310}

Date Coustruted: 1952 Year Closed:

Construetion Type: asbestos siding, asbestoe pipe insulation (416.10, p. 8, 12)

Size: $53 \times 30 \mathrm{ft}(414,01, \mathrm{p} . \mathrm{C}-8)$

Uniryue Featores: oquipped to handle two 10 to 14 tan cylinders simaltanoously, two roll up doors (414.01, p. C-8); 61 mottor tack (414.05, p.28)

Renoration: 1953: Thro months after opening- vemtlation system modified to accomodate lonal exhauss hoods posftioned over the pigtalis $(414.01, \mathrm{p} . \mathrm{C}-8$ ) Jartuary 1963: magnessum flucride pellet traps installed in product withdrawal station to rocover neptuming and fechmetiun (404.01, p. 17) 1983: Thodifications to the tack to reduer uratium tmissions (414.05, p. 28) no date foumd; Continuoas stack semplet for HP installed in C-310 stack. (414.05, p. 29)

By Oct. 1994: C-310 South Bank NaF Trap System completed

By Oct 1994: Seal Bxhast/Wot Alr Stations installed (425.01)

\section{Function-Table}

Year Function

1953 Froduct Witherawal Factitly (C-310A) $(404,0 \%, p, 53,402,01)$

1953 Purge and Product Bullding (406.01)

\section{Process-Table}

From year To year Process

In the cescades, UF6 passed through bartiers th the converters allowing lsotopes of kower molecular welght to pass through resulting In wo streams of UF5. The one with a progressively higher percentage U-235 was withdrawn in C-310. Product U-235 (enrkched UFe) Were withdrawn from the cascade by pumps that dlscharged through a condenses, piplng, and cylinder pigtalls to the intended recelving UF6 oylinder. Product oynlnders were not supposed to be filled to mome than 95 percent (llquid) of capacity. Those that were overfiled were tagged and subject to special handiling to resolve the overtilled condition. UFG cylinders still containing liquid could not be transported anound the site without special consideration. Before solid UFB cylinders were moved to storage, they were "burped" of light gases through sodium fluorifte traps. $(404.01$, p. 16, 53) 


\section{Contaminations/lncidents}

Year Contamination

One report Indicated that $20 \mathrm{dpm} / \mathrm{m} 3$ from Individual puffs based on test rup by entironmental committee. Maximum allowable is $20 \mathrm{dpm} / \mathrm{m} 3$. When there were large spilss, the premise was evacuated $(414,01, \mathrm{p}$. F-18)

An incident was reported in the $\mathrm{C}-310$ product withdratal building ( $\mathrm{C}-310 \mathrm{~A})$ where an Instrument heater control malfunctioned, melted tuking solder, and initiated a significant release that filed $\mathrm{C}-310$ and was working his way across the briofge to C-331. Alechanles were repontedly sent without PPE to shut doors in the bridge. The original instrument Ine leak was secured by crlmping the line by another worker outfilted in a Gra-Lite sult. Reportedly there there was no special monitoring of the involved indiniduals, and work resumed after the cloud dispereed, (404.01, p. 53)

The beta radiation dose rate at the surface of uranium metal is typically 230 millirems per hour or loss. Howewer, when uranfum is melted or separaled by chemlcal or physical means, less dense daughter producte of uranium, primarily thortum-234 and protactinium-234m, can be concentrated. When the uranium is further proceseed, signiffeant quantilies of these dalygter products can remain behind in the form of oxides or ash or on the strface of process vessels. Locatlons of daighter products at PGDP include C-310 in cylinder heels (feed and withdrawal). The beta radiation dose rate from these daughter producis is much higher tian that of the original ufenium. In addition, these daughter products are loose and eastly transferred by contact. Exposure to these daughter products as a result of transfer to clothing, toots, or other items is likely to resust in unanticlpated beta radiation toses to workers. Protactinlum-234m emils a hlghenergy beta particle, which contributes most of the beta dose from the uranium238 daughter products (404.01, p. 29)

1953 Based on process chemistry, neptunium and plutonitum concentrations would not be increased in the proctuct withctratal. Identified wipe data with elevated TRU levels confound this conclusion. (414.01, p. 25)

1953 Accidental UF6 releases during the connectlon and disconnection of cylinders was one of the leading causes of indivituals reporting to the dispensary for redical attention in 1953, according to \& PGDP quarterty report. UF6 leleseses often occurred when burping recently-fllled UF6 cylnders. (404.0r, p. 53) (not sure which bulditing)

1953 A fomer operations supervisor reported that operators turned up "hot in the product withdrawal erea more than any other area of the cascade. Fortions of the product withdrawal system operated at approximately 30 psig. As a result, smal leaks in this srea released enriched process gas into the room atmosphere and provlded a higher potenttal for an Intake. Air monltoring sampling indicated moderatehy high actiwity readings for the withdrawal room from the time of initlal operations up through the early 1960s. (404.01, p. 53)

1956 Year most uranium was released. $(414.05$, p. 28)

1958 A majot fire occusred in C-3to which hed a high poteintial for increased radiation exposure. Cari Walter stated that this fire resulted as a ditect result of high pressure on production (414.01, p. 48; 967.01, p. 27)

1989 Oct 1989-Release of urantum from ine C- 310 purge stack. Appjoximately 205 grams (a little less than $1 / 2$ pound) were released to the atmogithere when the pintinary and secondary trąp systam malfunctioned. (4 14.05, p. 33)

Pago 2 
1994 Some of the largest quantities of asbestos found at Paucah Gaseous Diffusion Plant were in C-310 (425,04)

2000 Puffs of gas sometimes occurred when the connectlon between the cylinders and the UF6 pipeline were broken whinout adequate purging. There were at least three instances where coupling between the cyinder and the gas line was broken, releasing large amounts of gas into the atmosphere. Primary exposutes were $\mathrm{UO} 2 \mathrm{~F} 2$ and $\mathrm{T} \mathrm{c}-9 \mathrm{\theta}$. (414,01, p. F-15)

2000 Releases of trapped gas were a froquent occurrence whale maintaining Instruments. (414.01, p. F-14)

2000 Workers had a potential radlation exposure when baghouse changing. (4 4 4.01, p. F-13)

Hazards: enriched UF6, sodiun fluaride (404.01, p. 53), noiso, heal, TCE, Te-99, ClF3, HF (967.01, p.29): beryllium (967.02), transuramics (414.01, p. F-13), asbestos $(425.04,416.10$, p. 8,12$)$

Inferred hezards:

\section{References}

402.01

404.0]

414.01

414,05

416,10

425.01

425.04

EBASCO Services Incorported OR-ERWM Propran Technikal Sumyasy Document for the ER of the GDPs.

Independent Investigation of the Padueah Gaseons Diffusion Plant, Phase ll, Prepared by Office of Oversigatt, Office of Brvironment, Sefety, and Health, U.S. Department of Energy, February 2000.

Exposure Asgessment Project at the Paducah Gaseons Plant Submitted by Paptr, Allied Industrial, Chemical and Energy Workers (PACE) Intertional Union, Uniwersity of Utah Division of Utah Division of Rodiology Center for Advenced Modical Tedmologies Centor by U.S. Departenont of Enargy Office of Environument, Safety and Health, Decembsr 2000.

Public Heatth Assossmeant Padunh Gaseons Diffusion (USDOE) Padacab, MaCracken

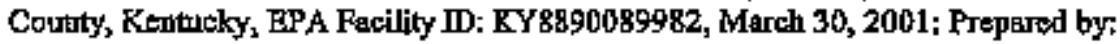
Energy Section Federal Facilities Assessment Branch Diviston of Health Asseasthent and Consultation Agency for Toxic Subatarces and Disoase Registry, bttp//wrww.stsdr,cdc.gow/HAC/PHA/paducah/ped_toc,html

Bxrracted ftom Document KZ-6945, Projoct Histery and Compietion Report- Paducah Atea Bare Program [As Rolaying to Work Pefformed by Ptime Contrastors, and Construction sub-contractors from November 1950 Through Febraty 1954]; Comptled by R.P. Prince, ETTP lnactive Records Center, Distribution of ETTP-33:2, USDOEHQ, Germantown, MD, Roger Anders, Bechtel Jacobs Company LLC, BMEF Inactive Resords Center (RC); Distribution of ETTP-3382, USDOE-HQ; Germantown, MD, Roger Anders, Bechtel Jacobs Company LLC. EMEP Inactlve Records Center (RC); April 2002.

Paducah Gaseous Diffision Plant; Natlonal Acadenny of Sciences National Reseanch Cormcil, Cornmittes on Decontarnination \& Decommissioning (D\&D) of the Uranitum Errrichment Facllities, Patucah Site Visit October 20, 1994.

Paducth Gascous Diffusion Plant- Congh̀derations Affceting D\&D, Stephen J. Dayls, D\&D Program Manager, June 15, 1994. 
Wages, R. ot al. Former Worker Medical Snevailince Program at Department of Enerey. 


\section{Portsmouth Former Worker's Program}

Health Conditions by Duration of Site Work from History, Lab Results, or Physician

Preliminary Data

Diagnosis Daseription

Abnormal Liver Furetion

Anemix

Arturitis, Deger, Joint Disesse

Ashestoris

Asthmin

Broschitis, Carrinie (Unspec)

Bursitis Disurders

Cancer. Bile duct

Cantert Blasder

Cancer: Bons

Cancta: Colon

Cancer: Gallblandier

Camcer: Kithey

Cancer. Layngen

Genoer: Leukenmin (OT chrJymph.leuk.)

Cancer: Long

Cancer: Multiple myelomen

Cances: Non-HFodgrín's lymphoma

Cancter- Onal-pharyaged

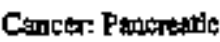

Cencer. Prostale
Possible Workplace Causative Exposiures

Solverats

Radigtion, Berrene

Lifting, bermmering, repetilive motoin

Apbestos

Dusts, chemicals

Particutates

Liffing, horsmaring, repetitive notiton

Rartiation

Cherricar cerninogens, radiation

Roliation

Rationtion

Rerixtion

Radíation, burmy metals, solveots

Rntiontion

Rodizition, Bemeane

Ratiation, nidket, welding immes, astbestos

Ratiation, benzens

Radiation, Benzeme

Radiatohn, benzente

Rentipation

Redifotion
Number In All

Workers Tested

Numbar in Workers 5

or thore Years at Slte
2!

$?$

37

I5

2 
Djagnosis Description

Cancer. Stan ancer of face

Cancer: Shin, Metentuma

Cencer. Skin, ron-melsporma

Cancer: Skin, Site Unspecified

Cancer: Stompach

concent Throat

Camcers Thyroid

Corpol Tumal Syadrofic

COPD

Derrestitio, Conket, dut to mortals

Destratifitis, Contact, NEC

Hearing Loss, Sensominoural

Hepatitis, Unspexdfied

Eyperthyroidism

Fypothyroidsm, Aequired, Unspec.

Lung mase

Larfg nodule[s]

Lung nodula, questionable

Neuropathy, Peripheral

Planzal Plaques

Ranal Failure

Rhimitits, Alletglc

Sartoidosis

Siricosis

Tbyroid disease

Tremter (Ungpecitaed)

\section{Posstble Workplace Ceusatlve Exposures}

Radiation, sumlight:

Radiation, surdight

Radiation, sumlight

Rediation, surlight

Radiation

Radiation

Rarijartion

Repetitive motion

Duste, mettils, wrelding fumes

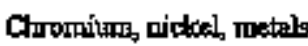

Allergens e.g. cement dingt, tickel

Noise

Solvents

Radiation

Rediation

Radiatican, astestos, ucasis

Radiotion, asbestos, metrils

Radintion, asbestos, metals

Snlvents

Asbestos

Metals, solverits

Dusts, solveots

Organic dust:

Sitica

Ratiation
Number in Al Workers Tested

Number in Workers 5 or More Years at site
2

35

2

121

35

121

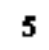

I

22

2

20

1

B

34 


\section{Paducah Former Worker's Program}

Aealth Conditions by Duration of Site Work from Hîstory, Lab Results, or Physician

\section{Preliminary Data}

Diegnosis Description

Abrommal Liver Fumetion

Abnorrwal Lung Fonchon

Areuria

Auturitie, Degen, Joint Discase

Asbestosis

Arthren

Bronchitis, Coronic (Uhoptes)

Bursitis Diforders

Canter: Bladder

Cancer Bont

Cancer: Colop

Comter: Esophrgeat

Cencor: Gellblandor

Cencert Hodjtin's diesase

Cancer. Kidnty

Canceri Latymgal

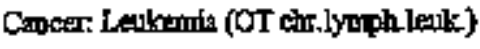

Cancer. Livex

Cmecr: Lung

Cancer. Multiple ㄸytelows

Cincert Non-Hodquin's byophoms
Possible Workplace Causativo Exposureg

Solvents

Asbestor, oition, dusts

Radiation, Benzene

Lifing homponing sepertivive motion

Asbestos

Dosts, chemicals

Partieulates

lifiting, hammering, repettive modon

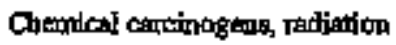

Rachiation

Radiation

Ractiarion

Raciation

Radiation

Radiation, beary metals, solvents

Rodiation

Rachintion, Brazenc

Reciotion, solvents

Radiption, nickel, welding formes, astestes

Ratiation, benizene

Reciotion, Berations
Number in Al

Workers Tested

Number in Wotkers 5 or More Years at Site

$\begin{array}{rr}28 & 6 \\ 209 & 21 \\ 42 & 5 \\ 239 & 36 \\ 201 & 19 \\ 39 & 7 \\ 76 & 7 \\ 48 & 8 \\ 9 & \\ 2 & \\ 15 & 1 \\ 1 & \\ 1 & \\ 1 & \\ 3 & \\ 3 & \\ 1 & \\ 2 & \\ 9 & 1 \\ 8 & 1 \\ 1 & \end{array}$


Appendix C

\section{Dlagnosis Description}

Merary Poisoming

Neuroparity, Petipheraid

Nodoie(s), lung, questionabio

Flearal Plaques

Rediation stchores, alcued, b/a

Renal Finure

Rhimitis, Alletgic

Slicosis

Skin cancer of fact

Thyrold disease

Thestoor (THzopecifiet)

Tremor from wethrury

\section{Posslble Workplece Causative Exposuros}

Mercury

Solvents

Ratiation, astestns, motals

Asbestos

Radiation

Metik, solvents

Dusts, solvents

Silica

Rudiation, samilight

Radiation

Mescury

Merewry
Number in Al] Workers Tested

Number In Workers 5 or More Years at Site

4

7

3 